\title{
TEACHER'S SPEECH CULTURE AND ITS COMPULSORY CATEGORIES
}

\author{
Nargiza Erkinovna Abdullaeva
}

PhD, Associate Professor, English Linguistics Department, National University of Uzbekistan

\section{ABSTRACT}

This paper discusses the role and value of teacher's speech culture in the process of teaching in education. Nowadays, a teacher is not only person who can teach, but also, he or she is a psychologist, orator, facilitator, leader, motivator, etc. Hence, teacher's speech has got several peculiarities that is included in teacher's speech culture. Moreover, there are some main categories of teacher's speech culture being compulsory in any teacher's speech, which make teacher's speech appropriate during the teaching process as well.

KEYWORDS: - Speech culture, pedagogical activity, teacher language, teacher's speech culture, normative aspect of speech, feasibility of speech, categories of teacher's speech culture.

\section{INTRODUCTION}

XXI century is the age of global reforms and scientific turns. The current stage of modernization of education put forward higher requirements for the training of teachers. This should be a creative minded person, communicative leader who can effectively influence the audience. Therefore, a prerequisite professionalism of the teacher is the high culture of his speech and writing.

Literature review

According to the S.D. Yakusheva, speech culture - a culture of personality that develops on the basis of objectively existing links between language and cognitive processes, suggesting a sense of style, taste and erudition developed [Yakusheva, 2011: p.59]. It should be mentioned that the topicality of forming speech culture of the teacher in the profession is obvious. As Kadyrova and Maimakova cited this obvious pedagogical value carries a speech culture of the teacher, which is a model of the native or non-native language, cultural voice of the younger generation [Kadyrova, Maimakova, 2013].

The modern age of information technology provides a person with the opportunity to manage large volumes of diverse information. There are many ways to receive it, to store, to transfer and change. Along with direct communication, indirect forms of communication are developing: telephone conversations, SMS correspondence, communication via video tools, email, social networks, instant messengers. On the one hand, this expands the possibilities of communication, and on the other hand, it leads to deterioration in interpersonal interaction skills, as well as to deformation of speech and its distortion 
CURRENT RESEARCH JOURNAL OF PHILOLOGICAL SCIENCES 2(11):

84-89, November 2021

DOI: https://doi.org/10.37547/philological-crjps-02-11-19

ISSN 2767-3758

(C)2021 Master Journals

\section{Crosser do) (81" Google}

Accepted25 $5^{\text {th }}$ November, 2021 \& Published 30th November, 2021

[Vakhterov, 2013]. In this regard, the problem of the culture of speech of people in general, and teachers, in particular, becomes relevant. Indeed, the specifics of pedagogical activity is due to the need for constant active contact with other people.

The work of the teacher is aimed at shaping the personality of a growing person, it contributes to the development of certain rules of behaviour, provides intellectual development of a person. In order to be able to interact correctly with other people, and especially with students, the teacher must possess not only special knowledge in the subject, but also professional communication skills. We can confidently say that the teacher's speech is the main tool of pedagogical influence and at the same time a model for students.

Despite the fact that in modern science there is an increased interest in the topic devoted to the culture of the teacher's speech as his professional tool, there are a number of issues requiring more detailed consideration. The task of the teacher is primarily to transfer knowledge and skills to their pupils. This is possible only through direct speech interaction with them. The enormous significance of the mission of the teacher cannot be denied. A complex and multi-component system of training and education is built on the relations between the teacher and students, through which the teacher penetrates the personal world of each student, introducing changes, developing their primary skills for improving their personality [Vakhterov, 2013: p.98].

A successful dialogue between a teacher and a student is possible only with the correct construction of an act of communication, which is a necessary component of the teacher's profession itself. When entering into interaction with other people, it is important to consider many elements, including the peculiarities of the views and positions of other people, the ability to conduct conversations on different topics, delimitation of communication areas, the ability to create a friendly atmosphere and etc. Therefore, one of the important professional qualities that any teacher should possess is the culture of his own speech. Pedagogical communication should be aimed not only at transferring knowledge and communication, but also at creating a favourable psychological climate. Improper communication of the teacher can lead to students' fear, insecurity, weakening of attention, memory, performance, impaired speech dynamics and, consequently the emergence of stereotypical representations. This is due to the fact that students have a reduced desire and ability to think independently. Ultimately, a steady negative attitude towards the teacher and the subject may exist.

Therefore, it will be correct to say that the communication of the teacher with the students should cause positive emotions that will stimulate the thirst for activity and the desire for selfimprovement. So, A.S. Makarenko concluded that "the main thing in communication between a teacher and students should be relations based on respect and exactingness" [Makarenko, 1951: p.256]. He considered pedagogical mastery as "the art of influencing the pupil, forcing him to experience and realize the need for certain behaviour" [Makarenko, 1951: p.254].

The role of Teacher's speech culture in education There may be an ask that why do we need to learn the Teacher's Speech Culture. There are main reasons listed above.

Firstly, teacher language - is a professional weapon, a tool with which completes and submits all thought. Because the specifics of the teaching profession are the constant activity of contact with other people. The work is aimed at the task of the teacher to form and elaborate the student's personality, the production of certain rules of behaviour, intellectual development. The teacher 
CURRENT RESEARCH JOURNAL OF PHILOLOGICAL SCIENCES 2(11):

84-89, November 2021

DOI: https://doi.org/10.37547/philological-crjps-02-11-19

ISSN 2767-3758

(C)2021 Master Journals

\section{Crossref do}

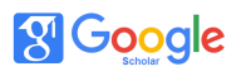

Accepted25 $5^{\text {th }}$ November, 2021 \& Published $30^{\text {th }}$ November, 2021

must have not only psychological, specialized knowledge, but also the professional communication skills, which are based on speech culture, which includes the norm and verbal skills.

Secondly, the teaching profession requires a broad general education and high moral qualities and professional skills. It is common knowledge that the teacher must be a person who goes ahead of the general education special because every day he has to deal with a variety of the phenomena of life, and these phenomena teacher should properly assess, to take the right decision for them and to make sure their point of view, accessing it children.

Thirdly, speech culture is not a private matter of the teacher, and social need. Teacher's morality prevents errors in his own speech and verbal identity. As teacher is a communicative leader, he is not only remembered, but also repeatedly played back. Approved teacher speech errors discredit teacher education in general. If the error went unnoticed, the teacher is a guide barbarism.

Fourthly, it is necessary to talk about the culture of the teacher's speech and because the words spoken by the teacher, have a major psychological impact. For example: each actual element: greeting, handling, post lesson topics, staging evaluation, comment on the answer, praise and blame - should have its own specific voicing, targeting their perception of speech or action algorithms. Violation of the rules of language teacher can cause a negative reaction on the part of the student.

Last, but not least, talking about the culture of the teacher should be the voice and because speech culture requires the ability not only to regulatory and better to build it, but to speak so that the source with the maximum fullness understood what was said. Volume of understanding - a reflection of the qualities of teacher's speech.

The normative aspect of speech is expressed in its grammatical correctness of conformity, orthoepy, accentology, vocabulary, phraseology, word formation, morphology, syntax.

Feasibility of speech is considered to be its conformity qualities such as accuracy, consistency, relevance, clarity, conciseness, effectiveness, expressiveness.

Thus, from the above that the teacher should have a voice culture, that is not only understand the importance of all elements of the language (words, different types of sentences, intonation), but also, as they use them in a literary language.

Formation of speech culture of the teacher is an important component in the development of his general culture. The notion of "speech culture" is the concept of "ideal speech" sample, according to which should be built right speech of a teacher.

It is also important to note that the teacher's speech is a kind of model for students. This leads to the fact that a number of requirements are imposed on it. T.V. Ivanchikova distinguished the following criteria [Ivanchikova, 2009: p.86]:

1. Speech should be as meaningful, accurate, logical as possible. The student must perceive all the semantic connections of the information he hears, and correctly find the logical conclusions. Therefore, the teacher should have a capability to accurately convey the necessary information, avoiding secondary elements that would interfere the perception.

2. Speech should be a model of lexical, phonetic, grammatical and orthoepic literacy. Nowadays, due to the high development of technology, the child is constantly faced with a huge stream of information, which is often replete with errors (media, advertising, etc.), therefore, in his social circle there should always be a person whom he could focus on when developing his own speech culture.

3. Speech should be distinguished by imagery and semantic expressiveness. Students should be interested in listening to information, and for this, the teacher's speech should have a high 
CURRENT RESEARCH JOURNAL OF PHILOLOGICAL SCIENCES 2(11):

84-89, November 2021

DOI: https://doi.org/10.37547/philological-crjps-02-11-19

ISSN 2767-3758

(C)2021 Master Journals

\section{Crosser do) (81" Google}

Accepted25 $5^{\text {th }}$ November, 2021 \& Published 30th November, 2021

level of creative element. But despite the fact that his speech should be emotionally saturated, it is necessary to observe the correct volume and timbre of speech, without rushing and without stretching the words, using rich intonations to create an easy-to-read speech text.

In addition to the above, it is vital for the teacher to have good diction, as well as mastery of the norms of speech etiquette, skilfully use non-verbal means of communication (gestures, facial expressions, pantomimic movements). Unfortunately, in the speech of the modern teacher there are a lot of clichés, (in the semantic aspect), simple sentences prevail grammatical errors, dialectisms are found. The teacher's speech culture is determined by the level of his general culture. The teacher's constant work on himself, raising the level of general culture will also contribute to the growth of his pedagogical skills.

Thus, we see that one of the most important components of the pedagogical skill of a teacher is his speech. This is an instrument of the teacher's professional activity, with which he can solve various pedagogical problems: to make the difficult topic of the lesson interesting, and the process of studying it - to be attractive, to create a sincere atmosphere of communication in the audience, to establish contact, to reach understanding with students; to form a sense of emotional security in them and instil their confidence [Adilova et all, 2010].

That speech culture of the teacher largely determines the quality of the educational process, creates favourable conditions for learning, education and development of students at all levels of education. In order to improve its speech culture, the teacher must constantly work on themselves, raising the level of general culture, which will undoubtedly contribute to the growth of his teaching skills, and therefore the success of professional teaching.

Compulsory categories of teacher's speech culture The following categories of teacher's speech culture are essential:

- correctness,

- accuracy,

- logicalness,

- expressiveness,

- richness,

- purity,

- appropriateness.

Correctness of teacher's speech is one of the main issues of teacher's speech culture as all other categories are formed around the correctness.

Because if the speech is not formed correctly, the other categories do not assist the speech to be more perfect. The category of correctness is evaluated according how a speech follows the norms and rules of a literal language. For instance, these literal norms of are distinguished in the Uzbek language:

1) lexical (using words) norms;

2) orthoepic (pronunciation) norms;

3) word formation norms;

4) morphological norms;

5) syntactical norms;

6) stylistic norms.

Moreover, there are orthographic and punctuation norms are defined in the written form of a literal language. Syntactical norms of English are more than Uzbek and Russian, because word order of the English language is not changeable as in both Uzbek and Russian.

Accuracy of teacher's speech provides the correct perception of speech by audience (listener(s)) as if there is not enough accuracy in speech then the audience of it may misunderstood the speech. Ancient Greek philosopher wrote: "if speech is not accurate, it will not reach its goal". Hence, if 
CURRENT RESEARCH JOURNAL OF PHILOLOGICAL SCIENCES 2(11):

84-89, November 2021

DOI: https://doi.org/10.37547/philological-crjps-02-11-19

ISSN 2767-3758

(C)2021 Master Journals

Crossref do

gil Google

Accepted $25^{\text {th }}$ November, 2021 \& Published $30^{\text {th }}$ November, 2021

speaker's intention is not concrete, then his speech never expresses accurate idea or thought. As Russian writer mentioned: "Inaccuracy in speaking words is the sign of inaccuracy of thought, of course". First of all, an object expressed in a speech situation and its name - word or word combination must fit to one another. A speaker and listener must know the lexical meaning of the words in speech well, moreover, it is considered to be oratory art to choose the appropriate word or word combination in speech. It deals with paradigmatic relations of words (polysemy, homonymy, synonymy, antonymy, meronymy, graduonymy, etc.). Secondly, in order to produce accurate speech a teacher has to know the grammatical meaning of a word or word combination and how to use it in speech properly.

As the Uzbek and English proverbs say: O'ynab gapirsang ham, o'ylab gapir; Avval o'yla, keyin so'yla; Yetti o'lchab, bir kes; O'n qatim o'yla, bir qatim so'yla; Think before speak; First think, then speak; Measure twice, cut once; Think twice, cut once; a teacher should think about what to speak beforehand, because his speech is educational frame for students. One cannot imagine the category of logicalness without correctness and accuracy of speech. Because these two categories provide logicalness of speech, of course, teacher's speech, too. The entire mutual concordance between semantic relations of words/sentences and logical sense of thought as well as its development in speech is called the category of logicalness.

Expressiveness is the category of speech that makes teacher's sentences touchable and interesting through using expressive means and stylistic devices in speech accordingly. Any speech aims to take listener's attention. So, a teacher also wants to the students listen to him attentively in order to understand and get knowledge from a lesson.
Teacher should make scientific-formal speech to hold a lesson, therefore the category of expressiveness is essential one to be in teacher's speech as without expressiveness teacher's speech is dull and vacuous. Especially in theoretical lectures if a teacher does not take the category of expressiveness in his speech into consideration, his students become bored and look forward to the end of the lesson as theory is difficult to comprehend itself. Hence, a teacher-lecturer should compile interesting and expressive speech including colourful examples from real life.

The category of richness is gained through using different language units (words, meanings, intonation, syntactical constructions, phrases, phraseological units (idioms), proverbs, etc.) in speech. The category of richness does not only make speech colourful and attractive, but also teach students new words in teaching a foreign language. Repeating the same word or word combination many times in speech is called "tautology". The Uzbek language is rich in various words owning denotational and connotational lexical meanings, that is why one should avoid tautology while forming good speech. As Alisher Navoiy wrote:

Bir deganni ikki demak xush emas,

So'z chu takror o'ldi dilkash emas.

Saying something twice is not enchanting,

The word repeated in speech is not captivating. (author's translation)

Lexical, semantic, grammatical (including morphologic and syntactical), intonational and stylistic variety makes speech rich and attractive at the same time.

An original and pure thing is always valuable in every society. A teacher's speech is very clear example for social communication, so its compulsory feature is the category of purity. This 
CURRENT RESEARCH JOURNAL OF PHILOLOGICAL SCIENCES 2(11):

84-89, November 2021

DOI: https://doi.org/10.37547/philological-crjps-02-11-19

ISSN 2767-3758

(C2021 Master Journals

Crossref do

8 Google

Accepted25 ${ }^{\text {th }}$ November, 2021 \& Published $30^{\text {th }}$ November, 2021

category is conveyed with making speech without any unit belongs to immoral and corrupted language. Even using a slang or jargon word damages the purity of teacher's speech. Moreover, purity of teacher's speech identifies his spiritual, moral, cultural and of course linguistic peculiarities. The following units are not characteristic to purity of teacher's speech culture:

1) dialectal words, phrases, grammatical forms, stress and pronunciation;

2) inappropriate usage of foreign words and phrases (barbarism);

3) slang and jargon words and phrases;

4) insulting and offensive words and phrases (vulgarisms);

5) parasite words;

6) bureaucratic language (very official words that are difficult to understand).

A teacher should avoid using these kinds of words in a class in order to make speech possessing the category of purity.

If there are all above-mentioned categories in speech, but there is not the category of appropriateness, these categories lose their sense. The category defines what to use, how to use, when to use, where to use, whom to use words and phrases in speech. Even one uses very good word in his speech but inappropriately his words are heard foolish by his auditory. This category demands not only to use appropriate words and phrases, but also to create appropriate interrelations among them in speech. It provides to express concrete intention of speech. Hence, the category of appropriateness is developed on the basis of the title of information conveyed in teacher's speech, its logical and emotional sense, cultural, spiritual and moral peculiarities of speech, informative, educational, aesthetic and other functions of written or oral speech.
To sum up, teacher's speech culture possesses great role and value in education as it has huge impact on our generation's future. A teacher has to know to listen students attentively, understand their ideas, mark their knowledge and give feedback them in order to increase their worldview and knowledge. Moreover, several phonetic features of teacher's speech such as sound, range, timbre, voice change, rhythm, tempo, accent and intonation are also considered to be main factors of successful speech in an auditory, which can be the objects of further researches.

\section{ReFERENCES}

1. Adilova Ch.A., Kushbakova R.Y., Mirzayeva F.B. Developing the speech culture of teachers. Problems of Science, № 1(49), 2020, pp.201-202.

2. Ivanchikova T.V. Speech competency or speech culture? Pedagogy, № 3, 2009, pp.8389.

3. Kadyrova G.R., Maimakova A.D. Culture of Russian Speech: linguistic norms and business communication. Textbook for students of Kazakh branches of pedagogical universities. Almaty, KazNPU Abay, 2013.

4. Makarenko A.S. Collection of favourite educator works (2nd ed.) under the general. ed. M., 1951, pp.386-391.

5. Vakhterov V.P. Fundamentals of new pedagogy: a monograph. M., Doe, 2013.

6. Yakusheva S.D. Fundamentals of teaching skills: a textbook. 4 th ed., Rev. and add. M., Academia, 2011. 